\title{
AC 2008-2415: TECHNOLOGY SKILL ASSESSMENT OF CONSTRUCTION STUDENTS AND PROFESSIONAL WORKERS
}

\section{Thuy Nguyen, University of Texas at Austin}

Thuy Nguyen is a research assistant at the University of Texas at Austin. She is pursuing her PhD studies in the program of Construction Engineering and Project Management. Her research interests include project management, instructional design, human resource management and educational psychology.

\section{Kathy Schmidt, University of Texas at Austin}

KATHY J. SCHMIDT is the director of the Faculty Innovation Center for the College of Engineering at The University of Texas at Austin. The FIC's mission is to provide faculty with effective instructional tools and strategies. In this position, she promotes the College of Engineering's commitment to finding ways to enrich teaching and learning. She works in all aspects of education including design and development, faculty training, learner support, and evaluation.

\section{William O'Brien, University of Texas at Austin}

Bill O'Brien's professional goals are to improve collaboration and coordination among firms in the design and construction industry. Dr. O'Brien specializes in construction supply chain management and electronic collaboration, where he conducts research and consults on both systems design and implementation issues. He is especially interested in the use of the information technologies to support multi-firm coordination, and has worked with several leading firms to implement web-tools to support practice. From 1999-2004, he taught in both the Department of Civil and Coastal Engineering and the M.E. Rinker, Sr. School of Building Construction at the University of Florida. Prior to returning to academia, Dr. O'Brien led product development and planning efforts at Collaborative Structures, a Boston based Internet start-up focused on serving the construction industry. Dr. O'Brien holds a Ph.D. and a M.S. degree in Civil Engineering and a M.S. degree in Engineering-Economic Systems from Stanford University. He also holds a B.S. degree in Civil Engineering from Columbia University. 


\title{
Technology Skill Assessment of Construction Students and Professional Workers
}

\begin{abstract}
In recent years, technology has been introduced to the construction jobsites at an increasingly rapid pace. As a result, there is a pressing need to increase the technology awareness and skill level of these practitioners and of those who are in academia. This new focus on technology education has to be incorporated first of all in the general curriculum and specific pedagogy of civil engineering programs at the university level as these are the source of next generations of leaders for the industry. In order to address this issue, we were awarded a NSF-funded project with two objectives: to identify the student and workforce learning characteristics in general, and to conduct an assessment of the current technology skills and knowledge of construction and engineering students and professional workers. These baseline data are being used to identify the needs of technology education for the construction workforce. More importantly, these findings are guiding the design and testing of prototypical technology-enhanced learning. This paper presents our initial findings from engineering students in our on-going research on effective pedagogy for technology-based construction education. In the paper, we will describe the design of the baseline data collection instruments that assess student technology skills and use of the learning module prototype, the most important findings from the data collected, as well as a discussion on the learning modules designed as a validation tool for our framework.
\end{abstract}

\section{Introduction}

Advanced cyberinfrastructure - particularly in information integration and sensor networks - is increasingly being developed to support the civil infrastructure of roads, bridges, buildings, etc. In particular, there is a call for the intelligent job site (IJS), which can be considered a domain specific instance of broader visions for ubiquitous computing. ${ }^{1}$ The intelligent job site seeks to revolutionize construction practice in terms of safety performance and productivity through distributed computing and deployment of a variety of sensors. A wide range of research and field trials are being conducted using IJS cyberinfrastructure, and specific applications have shown the potential of sensor and computing devices to affect practice. For example, earth moving has shown a significant increase in productivity by the use of terrain scanning, GPS, and laser devices directing equipment operations. ${ }^{2}$ Broad dissemination, however, of these technologies to the engineering and construction workforce has been painfully slow. There is a pressing need to disseminate IJS knowledge to practice, through both a novel pedagogy and by leveraging existing partnerships.

The intelligent job site (IJS) envisions the use of sensors, wireless networks, and mobile devices to augment capabilities commonly provided by centralized planning tools. Such augmented construction environments are relatively standard examples of ubiquitous computing, and many technical solutions cross domains other than construction. The basic rationale for IJS technologies is that improved state awareness will enhance productivity and safety. The development of inexpensive sensors and wireless devices (in particular, motes or devices designed with the intent of internetworking collections of sensors) makes deployment of the 
intelligent job site increasingly viable. Workforce education needs with respect to sensor and mobile deployment are large and include learning to make informed choices for sensor locations, the ability to make inferences from sensor data, and the ability to understand missing and/or conflicting readings from sensor data.

Why is education about IJS technologies challenging? Industry investment is generally low; a recent survey of information technology spending places construction at $\$ 250$ per employee, or $11^{\text {th }}$ on a list of 12 industries. ${ }^{3}$ By comparison, manufacturing is $6^{\text {th }}$ at $\$ 1000$ per employee. Furthermore, institutions of higher education may be limited at preparing a trained workforce. Currently the industry employs 7 million in wage and salary jobs and an additional 1.9 million through self employment and family business. ${ }^{4}$ A large and poorly educated craft labor force has limited capability to effectively deploy advanced technologies. The workforce is aging, and new entrants tend to be poorly educated and of minority status. ${ }^{5}$ Construction professionals in management roles are increasingly degreed engineers and architects. These professionals have strong basic computer skills, but traditional curricula lags research and practice in providing either specific knowledge of emerging IJS technologies or in providing the teamwork and leadership skills to aid technology dissemination among construction teams.

Despite the need for education on emerging IJS technologies in both industry and academia, there is relatively little progress being made. In this paper, we present a description of our solution - a core technical framework built using existing, open source based cyberinfrastructure and specifically directed to intelligent job site technologies. The key innovation of our approach is twofold: (1) we create a technical core that can support a variety of learning modules that introduce and reinforce the use of key technologies supporting intelligent job sites, and (2) each module can be rapidly customized to different learners' environments while maintaining pedagogical goals and consistency. We will share our initial ongoing findings from engineering students who have worked with the first module. We also describe the design of the baseline data collection instruments for the first component, the most important findings from the data collected, as well as a brief discussion on the learning modules designed as a validation tool for our framework.

\section{Description of Baseline Data Instruments}

To better educate students about technology, it is necessary to understand their current status of knowledge in this field in order to identify the areas of technology education to focus on.

Although there have been several quick check-lists available for organizations to determine their employees' skills of technology, these tend to be rather application-specific or provide simplistic Yes/No answers that are not significantly helpful in yielding insightful understanding about how an individual perceives, understands and evaluates technological concepts in the process of learning and self-improvement. More importantly, these check-lists do not establish a scale of technology skills and knowledge that can be used as a benchmark to facilitate accurate evaluation of technology educational tools or programs. Furthermore, as educators in a college environment, we have a strong desire in understanding the students' intellectual development process when technology is involved. 
As a result of these constraints, we decided to adopt a technological literacy development model called the Technology Arc developed by Langer and Knefelkamp ${ }^{6}$ for our design of the baseline technology skill assessment tool. This Technology Arc describes a model for understanding the students' progress in advancing their technological skills in college years. It is built upon the developmental models established by William Perry and Douglas Heath in the 1960s. It defines the developmental progress of a learner in five stages from low to high levels of intellectual development: Functional and Perceptual Knowledge, Multi-Tasking, Synthetic Awareness, Competence, and Multi-Dimensional. Five skills or literacies under consideration can be assessed against these scales to determine an individual's current status of knowledge; these are: Information/Computer Literacy, Interactions Literacy, Values Literacy, Ethical Literacy, and Reflective Literacy. Our baseline technology skills assessment tool is built upon the concepts of Langer and Knefelkamp's model. However, we modified the specific definitions of the developmental stages and replaced their five literacies by another five skill and knowledge areas that were more relevant to our student audience as described below. This is a linear model, which means that if one has reached a higher stage of development, one has acquired the skills and knowledge that are characteristic to the lower stages.

\section{Descriptions of developmental stages}

- Stage 1: Functional and Perceptual Knowledge. The learners with functional and perceptual knowledge understand the basic concepts and have the basic knowledge and skills of technology, including hardware recognition, software functions and the usage of internet-based applications. They can also communicate what they know with others effectively.

- Stage 2: Pluralist Awareness. Learners with technology awareness are aware of technical and non-technical (social, economic) benefits, constraints and limitations of technology. They are capable of developing multiple perspectives: being aware of the merits of technology and non-technology solutions in a certain context, and accepting the fact that others might have different perspectives on a solution or technology.

- Stage 3: Synthetic Awareness. Learners who are synthetically aware know how to integrate both technology and non-technology benefits in solutions. They become more coordinated and flexible at using technology. They are capable of updating and adjusting their values and beliefs as they develop new knowledge and skills of technology.

- Stage 4: Competence. Competent learners are able to evaluate the validity and credibility of technological products (such as information and feedback). Their knowledge, habits and skills of using technology have strengthened and become stable and readily accessible, which gives them the resilience to overcome and recover from unexpected problems.

- Stage 5: Proficiency. Proficient learners are motivated to apply and capable of using technology in contexts different from the original context in which the knowledge was acquired. They are able to judge independently and critically in any context, and hence become more willing to take risks. This ability encourages the learners to use technology for creative purposes. 
Once the developmental stages had been established, we chose the literacies or intellectual development areas that we wanted to measure. Among those used in Langer and Knefelkamp's Technology Arc, we retained the Interactions literacy, and slightly modified the Information/Computer literacy description to fit it under the umbrella of Operational Skills. We added three new literacies that were more relevant to technology-enabled instructional design; these are: Attitude (towards Technology), Cooperative Learning, and Active Learning.

\section{Descriptions of literacy/skill variables}

- Literacy 1: Attitude (towards Technology). This literacy variable is concerned with learners' awareness of various available technologies that could be used to improve their work as well as their social life and self-improvement. It also reflects the willingness to explore and adopt technology. Mature students become aware of state-of-the-art technologies relevant to their professional domain and personal needs. They are also receptive to change in their existing ways of doing things as well as to the adoption and adaptation of new technologies for better work performance.

- Literacy 2: Operational Skills. This literacy variable reflects the understanding of learners about the purposes and functionality of various technologies, the ability to use these features to perform the tasks at hand and develop more abstract knowledge. As learners mature, they can operate devices or use applications with ease to serve their specific purposes. They also learn through reflecting on the process, the system and the conceptual rationale behind these specific functions to form more integrated and comprehensive knowledge of how to maximize operational benefits of technology.

- Literacy 3: Interactions. This literacy variable relates to how cyber-infrastructure, including the world of mobile technologies and Internet-based applications, can influence students' relationships with others in terms of communication and respect for individual differences in the virtual world. The mature learners understand differences between asynchronized and real-time communication, and face-to-face and distant communication. They adapt well, both cognitively and emotionally, with this new form of communication that technology brings about, and develop tolerance for others' habits and methods of communication.

- Literacy 4: Cooperative Learning. This literacy variable is associated with the ways learners use technology collaboratively to complete a common task that serves both a common goal and individual needs. Mature individuals can use technology to maximize the learning of self and help others achieve their goals, in addition to the common goals. They are capable of using technology to make everyone a better resource for others. Maturing individuals become increasingly aware of the benefit of investing in others for their own intellectual achievement, and committed to cooperation for realizing that potential.

- Literacy 5: Active Learning. This literacy variable reflects the awareness, willingness and ability of learners to make use of available technology to actively involve in various intellectual activities with self and others. Mature individuals can retain knowledge for 
long-term, are motivated for further learning, confident and effective in applying current knowledge as well as acquiring new knowledge with minimal instruction.

A sample graphical representation of the Technology Arc resulted from our baseline technology skill assessment tool is shown in Figure 1. In this example, the student has acquired synthetic awareness in the Attitude and Cooperative Learning literacies, pluralist awareness in Interactions and Active Learning, and has reached competence in Operation Skills.

\begin{tabular}{|c|c|c|c|c|c|}
\hline \multicolumn{6}{|l|}{ Maturity Stages } \\
\hline $\begin{array}{l}\text { Proficiency } \\
\text { (Stage 5) }\end{array}$ & & & & & \\
\hline $\begin{array}{l}\text { Competence } \\
\text { (Stage 4) }\end{array}$ & & & & & \\
\hline $\begin{array}{l}\text { Synthetic Awarenes } \\
\text { (Stage 3) }\end{array}$ & & & & & \\
\hline $\begin{array}{l}\text { Pluralist Awareness } \\
\text { (Stage 2) }\end{array}$ & & & & & \\
\hline $\begin{array}{l}\text { Functional and Perce } \\
\text { Knowledge } \\
\text { (Stage 1) }\end{array}$ & & & & & \\
\hline Literacy Variables & Attitude & $\begin{array}{l}\text { Operational } \\
\text { Skills }\end{array}$ & Interactions & $\begin{array}{l}\text { Cooperative } \\
\text { Learning }\end{array}$ & $\begin{array}{l}\text { Active } \\
\text { Learning }\end{array}$ \\
\hline
\end{tabular}

Figure 1. Technology Arc for Baseline Technology Skill Assessment

This figure is the output of the assessment tool, which can be used to identify areas that need to be focused on when designing and/or conducting instruction. The shaded cells reflect the knowledge the student has gained, and the white cells reflect the learning to be achieved. It should be noted that although this student has "passed" through Functional and Perceptual Knowledge and Pluralist Awareness in using technology to enhance Active Learning skills, it does not mean that there is nothing left under those cells for the student to learn or improve. A shaded cell just means that the student has substantially mastered the skills in that stage. Similarly, a white cell does not mean the student has acquired nothing of the knowledge or skills corresponding to the Synthetic Awareness stage of Active Learning. He or she might have acquired some, but has not reached the substantial limit to be granted the cell.

To determine which "cells" of the arc a student has acquired or mastered, we use a comprehensive self-assessed questionnaire which is our baseline technology skill assessment tool. The questionnaire has three main parts: Demographic and Background Information, Technology Exposure Checklist, and Technology Skill Assessment. Part 1 captures the basic information about the participants, such as age, gender, academic background, construction experience, and English proficiency. Part 2 is a check-list of popular technologies to determine the participants' awareness of the existence of these technologies and corresponding levels of use. Part 3 is a set of 42 statements about technology; for each of these statements, the 
participants are asked to rate its relevance to their field, their understanding about specific applications mentioned in the statement, and their experience in using such applications. A 5point Likert scale is used for all questions. The scores from these 42 questions are used to determine the status of the 25 cells in the arc matrix. Some cells have input from one question if the aspect under investigation does not require multiple inputs. Some others are more complicated and have more than one dimension for assessment. These require input from two or three questions in the survey. This is where the elegance as well as the complexity of the design lies. The questionnaire can always be expanded to get more input for each cell so that some redundancy can be built in. However, as more questions are introduced, there are more factors that can affect the model's linearity which is already difficult to ensure even with a simple questionnaire. Furthermore, long surveys might have an impact on the psychological reaction of participants, which might affect the accuracy of answers given.

The second baseline data instrument used in our research is the Index of Learning Styles Questionnaire developed by Felder and Soloman at the North Carolina State University. ${ }^{7}$ This is an instrument that has been widely used among many engineering students to determine their preferred styles of learning among four dimensions: Active versus Reflective, Sensing versus Intuitive, Visual versus Verbal, and Sequential versus Global. We wanted to capture this information as the starting point for the pilot design of our learning modules.

\section{Findings from Initial Deployment of Baseline Data Instruments}

The baseline technology assessment survey was used by 55 engineering students at the University of Texas at Austin and the University of Kentucky in the fall of 2007. The background of these participants is summarized in Table 1.

Table 1. Demographic background of survey participants

Age

\begin{tabular}{ll}
\hline $18-25$ & 48 \\
\hline $26-35$ & 7 \\
\hline Over 35 & 0 \\
\hline $\begin{array}{l}\text { TOTAL } \\
\text { (participants) }\end{array}$ & $\mathbf{5 5}$
\end{tabular}

Highest education level

\begin{tabular}{ll}
\hline Sophomore & 1 \\
\hline Junior & 26 \\
\hline Senior & 27 \\
\hline Graduate school & 1 \\
\hline \hline $\begin{array}{l}\text { TOTAL } \\
\text { (participants) }\end{array}$ & $\mathbf{5 5}$
\end{tabular}

Gender

\begin{tabular}{ll}
\hline Female & 13 \\
\hline Male & 42 \\
\hline \hline $\begin{array}{l}\text { TOTAL } \\
\text { (participants) }\end{array}$ & $\mathbf{5 5}$
\end{tabular}

\section{Construction Experience}

\begin{tabular}{ll}
\hline None & 29 \\
\hline$<2$ years & 25 \\
\hline 2 to 5 years & 0 \\
\hline$>$ 5 years & 1 \\
\hline \hline $\begin{array}{l}\text { TOTAL } \\
\text { (participants) }\end{array}$ & $\mathbf{5 5}$
\end{tabular}

The average scores of all responses corresponding to the 25 cells of the baseline matrix are shown in Figure 2. The baseline assessment survey is an individual self-assessed tool yet we look 
at the results in aggregate. Inventories, such as this one that are self-report instruments can have validity issues. Validity hinges upon respondents' ability to read and understand the questions, their understanding of themselves, and their willingness to give honest responses. Using this inventory with college students should not result in comprehension problems and there aren't responses that could be linked to being more socially desirable.

The results show that the majority of college students in the two schools surveyed demonstrate high to very high maturity in technology skills. They are in general highly aware of most of the relevant technologies in their fields of study although they do not always understand the science behind them. For those technologies that they have had limited exposure to, most students show a positive attitude toward them and are willing to learn more about their applications.

\begin{tabular}{|c|c|c|c|c|c|}
\hline Maturity Stages & & & & & \\
\hline $\begin{array}{l}\text { Proficiency } \\
\text { (Stage 5) }\end{array}$ & 3.76 & 3.22 & 3.72 & 3.75 & 3.42 \\
\hline $\begin{array}{l}\text { Competence } \\
\text { (Stage 4) }\end{array}$ & 3.83 & 3.75 & 3.53 & 3.39 & 3.64 \\
\hline $\begin{array}{l}\text { Synthetic Awareness } \\
\text { (Stage 3) }\end{array}$ & 3.75 & 3.95 & 3.66 & 3.23 & 3.45 \\
\hline $\begin{array}{l}\text { Pluralist Awareness } \\
\text { (Stage 2) }\end{array}$ & 3.59 & 4.02 & 4.12 & 3.45 & 3.22 \\
\hline $\begin{array}{l}\text { Functional and Perceptual } \\
\text { Knowledge } \\
\text { (Stage 1) }\end{array}$ & 5.00 & 4.60 & 4.40 & 3.82 & 3.33 \\
\hline Literacy Variables & Attitude & \begin{tabular}{|c|}
$\begin{array}{c}\text { Operational } \\
\text { Skills }\end{array}$ \\
\end{tabular} & Interactions & $\begin{array}{l}\text { Cooperative } \\
\text { Learning }\end{array}$ & $\begin{array}{c}\text { Active } \\
\text { Learning }\end{array}$ \\
\hline
\end{tabular}

Figure 2. Average scores of all participants

Figure 3 provides the percentage of participants who scored between 4 and 5 in each cell, which was the highest score range in the 5 point scale. As can be seen from Figures 2 and 3, it was a common trend for students to score higher in Attitude, Operational Skills and Interactions compared to Cooperative Learning and Active Learning, especially for the first three developmental stages. This suggests that these last two area of knowledge and skills might be harder to acquire than the first three, and need to be studied further.

It should also be noted that for some literacies, average scores for some higher level cells were higher than those for the lower level cells (Figure 2), or more students had earned some higher level cells than lower one in the same literacy (Figure 3). This reflects the fact that the model has not achieved complete linearity and need to be validated and refined. Individual technology arcs should be analyzed to identify areas where nonlinearity occurred, and questions corresponding to those areas need to be reexamined to refine the design of the assessment tool. 


\begin{tabular}{|c|c|c|c|c|c|}
\hline Maturity Stages & & & & & \\
\hline $\begin{array}{l}\text { Proficiency } \\
\text { (Stage 5) }\end{array}$ & $24 \%$ & $18 \%$ & $33 \%$ & $33 \%$ & $16 \%$ \\
\hline $\begin{array}{l}\text { Competence } \\
\text { (Stage 4) }\end{array}$ & $29 \%$ & $27 \%$ & $20 \%$ & $22 \%$ & $22 \%$ \\
\hline $\begin{array}{l}\text { Synthetic Awareness } \\
\text { (Stage 3) }\end{array}$ & $22 \%$ & $40 \%$ & $22 \%$ & $15 \%$ & $18 \%$ \\
\hline $\begin{array}{l}\text { Pluralist Awareness } \\
\text { (Stage 2) }\end{array}$ & $22 \%$ & $40 \%$ & $45 \%$ & $13 \%$ & $13 \%$ \\
\hline $\begin{array}{l}\text { Functional and Perceptual } \\
\text { Knowledge } \\
\text { (Stage 1) }\end{array}$ & $100 \%$ & $64 \%$ & $58 \%$ & $33 \%$ & $13 \%$ \\
\hline Literacy Variables & Attitude & $\begin{array}{l}\text { Operational } \\
\text { Skills }\end{array}$ & Interactions & $\begin{array}{l}\text { Cooperative } \\
\text { Learning }\end{array}$ & $\begin{array}{c}\text { Active } \\
\text { Learning }\end{array}$ \\
\hline
\end{tabular}

Figure 3. Percentage of participants with scores between 4 and 5 in each cell

Another trend found from our initial survey results is the tendency of students to have stronger knowledge in the areas of Attitude, Operational Skills and Interactions. That is, they are generally positive and explorative towards technology; they are able to operate basic technologies reasonably well, and they know how to take advantage of the communicational benefits from new technologies (such as emails, forums, and instant messaging tools). However, fewer students have extensively used technology to promote cooperative and active learning to its highest capacity. This finding might suggest that some adjustment is to be made to the way we teach students so that they are encouraged to take more advantage of technology to support these two highly desired and effective methods of learning.

\section{Descriptions of Learning Module}

To demonstrate that technology can be used effectively in teaching to promote active learning and accommodate different learning styles, the project team has developed a learning module and pilot tested it with 10 students at the University of Texas at Austin. The learning module is a material management exercise which is designed to be a stand-alone computer software installed on a tabletPC. The infrastructure of this learning module also includes several sensors that communicate with the tabletPC to generate RFID-like data to feed to the material management exercise. Figure 4 shows the interactive user interface of the learning module. In this exercise, the students carry the tabletPC and walk around a virtual jobsite. As they walk around, the sensors send the data to the tabletPC which are displayed in the RFID Data panel of the interface. Their task is then to locate these materials on the map of the site that they have, and validate the construction schedule provided. This learning sequence is illustrated in Figure 5. 


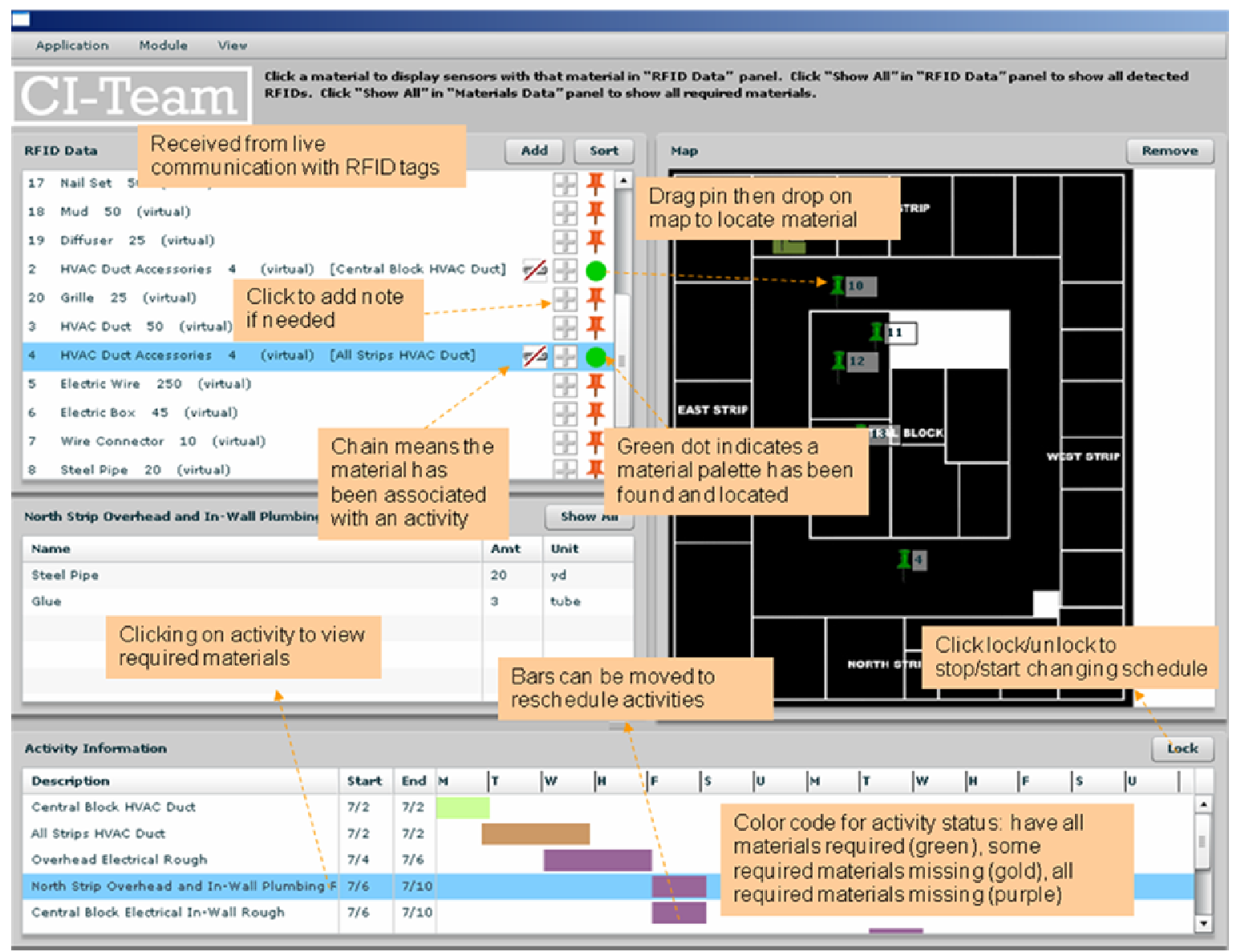

Figure 4 . The interactive interface of the learning module

\section{Step 1}

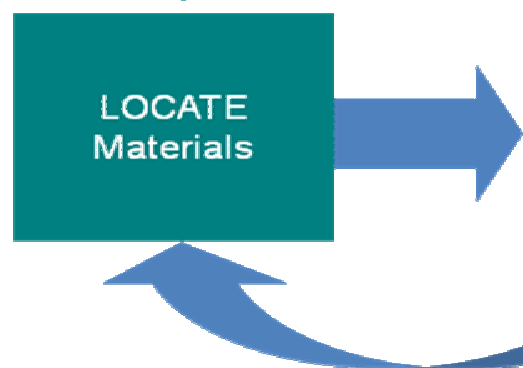

Application: Material

identification

\& association with sensors

Step 2
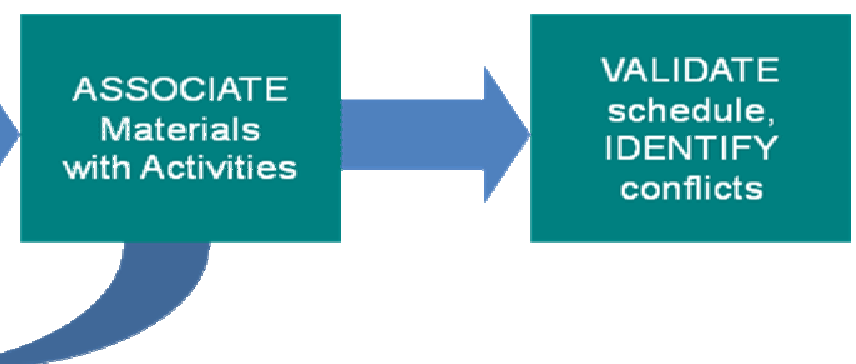

Application/Analysis:

Schedule discovery and relation to materials

(spatial reasoning)

\section{Step 3}

VALIDATE

schedule,

IDENTIFY

conflicts

\section{Key pedagogical objectives}

Figure 5. Learning sequence of material management exercise

In the testing done at the University of Texas at Austin, the virtual jobsite used was the fifth floor of the civil engineering building, with the map shown in Figure 4. The map was drawn purposely like a 2-D engineering drawing with black background and white lines as this would be the kind 
of drawings used on most construction jobsites. There were offices all around and in the central block. Sensors were hidden in the ceiling along the corridor. As the students carried the tabletPC and walked along the corridor, they had to look for the materials that were supposed to be physically present on the jobsite (which were presented by big paper signs). Live RFID-like data generated by sensors were displayed on the tabletPC (top left corner panel in Figure 4) which allowed students to compare what they saw with their own eyes and what was detected by the tabletPC, and then take actions.

Although this is a simple exercise, it demonstrates the attractiveness of technology when incorporated properly in the design of pedagogical tools. The initial feedback (collected from a questionnaire) we got from students is generally positive. As the exercise content is very relevant to their study, the technology makes more sense, especially when they have a chance to actively carry out tasks that are very interactive in nature. We plan to conduct several more tests in order to obtain enough understanding about the high level of learning that occurs when students interact with advanced technologies like this, and whether or not the designs are adaptive to different learning styles.

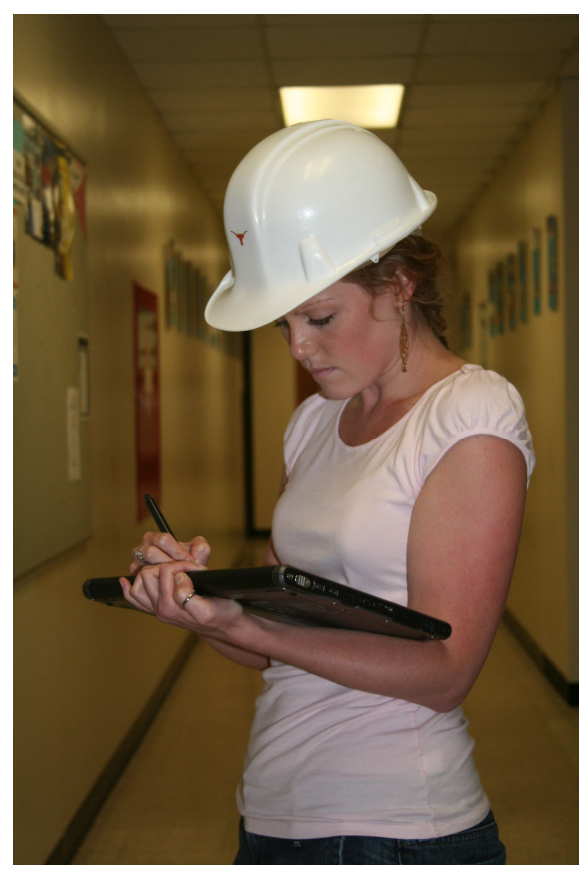

Figure 6. A student in action in corridor

\section{Discussions and Conclusions}

The baseline technology skill assessment tool has been designed to comprehensively capture the intellectual development process that students engage in when they use technology in various activities, both academically and non-academically. It is built upon previous models of intellectual development and adapted to suit the nature and needs of civil engineering students. The initial findings from the first deployment of the survey tool at the University of Texas at Austin and the University of Kentucky show that the tool captures some insightful information about the way the students react to technology and develop their intellectual power. Due to the complexity and the abstractness of the domain, there is a need to further refine and validate the tools to ensure its accuracy and strengthen the linearity of the model.

The research team plans to extend the implementation of this survey to several other civil engineering schools across North America to build a database for refinement and validation. The next step to this would be to adapt the survey questionnaire so that it is suitable for determining the technology skills of construction workers.

\section{Acknowledgements}

We would like to acknowledge the support of the National Science Foundation, the University of Kentucky and several students who have participated in our survey and learning module testing. 


\section{Bibliography}

1. Wesier, M. (1991). The Computer for the Twenty-First Century. Scientific American, 265(3), 94-101.

2. Gambatese, J. and Dunston,P.( 2003).Design Practices to Facilitate Construction Automation, RR183-11, Construction Industry Institute, Austin, Texas.

3. Economist. ( 2005). The No-computer Virus. The Economist, 253(19), 65-67.

4. BLS. ( 2006). Career Guide: Construction., U.S. Department of Labor Statistics.

5. O'Brien, W. J., Soilbelman, L., and Elvin, G. (2003).Collaborative Design Processes: An Active- and Reflective Learning Course in Multidisciplinary Collaboration. Journal of Construction Education, 8(2), 78-95.

6. Langer, A. and Knefelkamp, L. (2008). "Technological Literacy Development in the College years: A Model for Understand Student Progress". To be published in the Journal of Theory to Practice, Summer 2008.

7. Felder, R. M. and Soloman, B. A. (1991). Index of Learning Styles.

http://www.engr.ncsu.edu/learningstyles/ilsweb.html accessed 1/10/08 